\title{
The Determinants of Money Demand in Jordan: ARDL Approach
}

\author{
Ali Mustafa Al-Qudah \\ Department of Finance and Business Economics \\ Faculty of Economics and Administrative Sciences \\ Al Al-Bayt University, Mafraq, Jordan \\ E-mail: alimqf@yahoo.com
}

Received: Nov. 30, 2018

Accepted: Jan. 14, 2019

Published: January 24, 2019

doi:10.5296/jmr.v11i1.13771

URL: https://doi.org/10.5296/jmr.v11i1.13771

\begin{abstract}
The current study examined the relationship between real money demand (M2) and its determinants represented by real gross domestic product, real interest rate, inflation rate and budget deficit in Jordan for the period (2000Q1-20018Q1). The study used unit root test, Autoregressive Distributive Lag (ARDL), cointegration and long run, bound test to examine the study hypotheses. ARDL cointegration equation and ARDL Bound test show that there is a long run relationship between money demand M2 and its determinants, real interest rate, inflation rate, budget deficit and real gross domestic product. The short run ARDL results shows that the past period of money demand has a negative and significant impact on money demand, while inflation rate and Gross domestic product have a positive and significant impact on money demand in Jordan. The long run ARDL results show that the inflation rate, real gross domestic product and budget deficit have a positive long run relationship with money demand $\left(\mathrm{M}_{2}\right)$ and Its impact on $\left(\mathrm{M}_{2}\right)$ is positive and statistically significant at 1 percent level, while interest rate has a negative and significant impact on Money demand $\left(\mathrm{M}_{2}\right)$. Inflation rate, real gross domestic product, budget deficit and interest rate are good determinants for money demand M2. The cumulative sum (CUSUM) of recursive residuals and cumulative sum of squares (CUSUMQ) of recursive residuals confirm that the estimated money demand M2 model is stable.
\end{abstract}

Keywords: ARDL, Bound test, long run, short run, CUSUM, Jordan, Money demand. 


\section{Introduction}

The demand for money is the basis for reviewing the effectiveness of monetary policy, as an important issue in influencing the overall stability of the economy. The demand for money is important in the formulation of appropriate monetary policy. For this reason, there is an urgent need to understand the demand for money at the macro level, which must be under the control of the monetary authorities represented by the Central Bank of Jordan in Jordan, In view of the importance of demand for money and its relation to macroeconomic variables such as interest rate, economic growth, inflation, budget deficit and other macro variables, the demand for money gives the monetary authorities the ability to make changes in macroeconomic variables, It is worth mentioning that there is a great interest of economists in the total demand for money because the instability of economic variables, It is possible to lead to unstable demand for money.

Demand for money is considered as an important indicator of economic growth, since the increase in demand for money often indicates an improvement in the economic situation in the country, in contrast to the decline in the demand for money, which often refers to the deterioration of the economic situation. Monetarism emphasizes on the importance of the role of governments through central banks in controlling the size of money circulated in the economy. They also believe that the change in monetary supply has a significant impact on national product in the short run and on the general price level in the long run. the monetarism including neo-Keynesians supposed that the demand for money is fundamental of supply for money. Unlike some conservatives who believe that the demand for money is unpredictable.

The concept of demand for money in the short-run is that the low demand for money in the economy can lead to an increase in demand for money regardless of the real production movement. While the concept of money demand in long-run is that if the growth of production relates to the demand for money in the long term, this means that the increase in the money issue that is appropriate to the stability of prices may be achieved in the long run (Maravić and Palić 2010, Dritsakis,2011).

The Central Bank of Jordan used a monetary policy aimed to keep the supply and demand for money in equilibrium. The Central Bank of Jordan is constantly trying to put in place the optimal money supply that can achieve macro-economic objectives of Jordan economy.

There are many factors that affect the demand for money. If the demand for money is stable, the central bank adopts a monetary policy to influence the important macroeconomic variables. The success of the central bank's policy depends on the relationship between the demand for money and its determinants. (Baharumshah, et al. 2009, Dritsakis, 2011).

The purpose of this study is to investigate the empirical relationship between real money demand $\mathrm{M} 2$ and its determinants represented by, real gross domestic product (RGDP), inflation rate (INFR), budget deficit (BD) and real interest rate (INTR), by using the autoregressive distributed lag (ARDL) long run and cointegration approach.

This study involves five sections. Section one introduction, section two literature review, section three data and methodology, section four empirical results and section five conclusions. 


\section{Literature Review}

There have been a number of studies that have examined the demand for money and its determinants in developing and developed countries. These studies have used different statistical techniques, some of these studies are:

The study of Abakpa, Purokayo, Asaph and Asaph(2018) examined the impact of consumer price index, gross domestic product, interest rate, and foreign direct investment on money supply in Nigeria for the period (1981- 2015), they used Autoregressive Distributive Lag(ARDL) model to examine their study hypotheses, the results shows that the short run and long run relationship exist between money supply and its determinants.

Ebele and Omontag (2015) investigated the effect of inflation, gross domestic product and exchange rate on broad money supply $\left(\mathrm{M}_{2}\right)$ in Nigeria for the period 1981-2-13, they used cointegration and multiple linear regression and OLS method to examine the effect of independent variables on dependent variable, they found that GDP has a positive and significant impact on money supply and the cointegration test shows a long run relationship between variables.

Melih ÖZÇALIK (2014) estimated the relationship between $\left(\mathrm{M}_{2}\right)$ and interest rate, exchange rate and GDP in Turkey for the period 1995:Q4-2013:Q3, he used ARDL approach to test the long run and short run relationship between $\left(\mathrm{M}_{2}\right)$ and interest rate, exchange rate and GDP, he found that there is a long run and short run relationship between $\left(\mathrm{M}_{2}\right)$ and interest rate, exchange rate and GDP in Turkey, the interest rate has a positive and significant impact on $\left(\mathrm{M}_{2}\right)$, according to CUSUM and CUSUM-Q tests he found that money demand function is stable in the first test, while it's not stable in the second test even in the long-run and short-run.

Abdullah, Chani, and Ali(2013) examined the determinants of broad money demand $\left(\mathrm{M}_{2}\right)$ in Pakistan for the period 1972-2010, they use households consumption expenditure, investment expenditure, government expenditure, exports expenditure and price level, as independent variables, and they used cointegration and Vector Error Correction Model(VECM) to examine their study hypotheses, they found that there is a long run relationship between money demand $\left(\mathrm{M}_{2}\right)$ households consumption expenditure, investment expenditure, government expenditure, exports expenditure and price level, and they found that households consumption expenditure, investment expenditure and exports expenditure have positive and significant relationship with money demand $\left(\mathrm{M}_{2}\right)$, while they found that government expenditure and price level have a negative and significant relationship with money demand $\left(\mathrm{M}_{2}\right)$.

Abdulkheir (2013) investigated the long run relationship between money demand(M2) and real GDP, interest rate, real exchange rate and inflation rate, in Saudi Arabia for the period 19872009 and he used cointegration test and the vector error correction model (VECM) technique. he found that there is a long run cointegration relationship between the demand for money (M2) and real GDP, interest rate, real exchange rate and inflation rate.

Doğru and Recepoğlu (2013) investigated the dynamic determinants of money demand function proposed in Turkey for the period 1980 to 2012. the study used (M2) as dependent variable and real product and nominal interest rate as independent variables. They used vector 
error correction, dynamic ordinary least squares (DOLS) and fully modified OLS (FMOLS) techniques. The estimation results shows a long-run relationship between money demand, real product and nominal interest rate . But the long run-coefficients estimated from FMOLS and DOLS is smaller than that of the Johansen co-integration vectors. Nevertheless, real money demand in Turkey is positively related with real product and negatively related with nominal interest rates.

Dritsakis (2011) examined the determinants of demand for money in Hungary for the period 1995:1-2010:1 using the autoregressive distributed lag (ARDL) cointegration framework. The empirical results show that there is a unique cointegrated and stable long-run relationship among M1 real monetary aggregate, real income, inflation rate and nominal exchange rate. they found that the real income elasticity coefficient is positive while the inflation rate elasticity and nominal exchange rate are negative. This indicates that depreciation of domestic currency decreases the demand for money. The results also reveal that after incorporating the CUSUM and CUSUMSQ tests, M1 money demand function is stable.

Achsani (2010) investigates the impact of real income and interest rate on (M2) money demand for Indonesia in the period of 1990:1-2008:3. The results indicate that the demand for real M2 money aggregate is cointegrated with real income and interest rate. The real income has positive relationship with real money demand, both in the long-run and short-run. On the other hand, interest rate has a negative influence on M2 in the short-run, but has no statistically significant relationship in the long-run.

Baharumshah, et al. (2009) investigated the demand for broad money (M2) in China for the period 1990:Q4 - 2007:Q2. using the autoregressive distributed lag (ARDL) cointegration. The results based on the bounds testing procedure confirm that a stable, long-run relationship exists between M2 and real income, inflation, foreign interest rates and stock prices.

Samreth (2008) examined the money demand function in Cambodia using monthly data for the period 1994:12-2006:12. To examine the study hypotheses he used the autoregressive distributed lag (ARDL) approach . The results show that there is a co-integrating relationship among variables (M1, Industrial Production Index, Consumer Price Index, and Nominal Exchange Rate) in money demand function. CUSUM and CUSUMSQ tests roughly support the stability of estimated model.

The previous studies used different techniques to examine the relationship between money demand (M2) and its determinants Melih 2014, Dritsakis 2011 and Baharumshah, et al. (2009) they used ARDL approach, Abdulkheir (2013) and Abdullah, Chani, and Ali(2013) used VECM, while Doğru and Recepoğlu (2013) used OLS, and they used different determinants factors such as, Industrial Production Index, Consumer Price Index, and Nominal Exchange Rate, real income, inflation rate, foreign interest rates and stock prices.

The present study is an extend to the previous studies, to examine the relationship between real money demand M2 and its determinants represented by real gross domestic product (RGDP), inflation rate(INFR), real interest rate (INR), and budget deficit (BD), the current study has a contribution in the literature represented by adding budget deficit as a determinant for money 
demand in addition it's a proof on the determinants of money demand from Jordan as a developing country. The study used ARDL long run and cointegration approach and stability test, to examine the relationship between money demand M2 and its determinants.

\section{Data and Methodology}

\subsection{The Data}

This study used quarterly time series data for the period (2000:Q1-2018:Q1) collected from the Central Bank of Jordan database. money demand $\left(\mathrm{M}_{2}\right)$, interest rate (INTR), inflation rate, (INFR) budget deficit (BD) and real gross domestic product (RGDP).

\subsection{Methodology}

There are different techniques used to analyze the cointegration between variables. The cointegration approaches of Engle and Granger (1987), Stock and Watson (1988), Johansen $(1988,1991)$ and Johansen and Juselius (1990) can be used only if the variables time series have the same order of integration, But in fact because of the shocks and the time trend it is difficult for all time series to have the same degree of integration, since some time series are stable at level $\mathrm{I}(0)$ and some at the first difference $\mathrm{I}(1)$. In such these cases the cointegration approaches of Stock and Watson (1988), Johansen (1988, 1991)and Johansen and Juselius (1990) can't be used. to overcome this problem Autoregressive Distributed Lag (ARDL) approach was established by Pesaran and Pesaran (1997), and Pesaran and Shin (1995, 1998), later on it was further organized by Pesaran, Shin and Smith (2001). (ARDL) can be applied if all the time series are stationary at level I(0) or if all the time series are stationary at level I(1) and if they are a combination of $\mathrm{I}(0)$ and $\mathrm{I}(1)$ but it can't be used if one of the time series is stationary at $\mathrm{I}(2)$. The ARDL model is a combination of autoregressive model and distributive lagged model, Therefore, the time series is not only a function of its lagged values but also its a function of the current values and the lagged values of one or more variables. The ARDL has only one cointegration equation. The ARDL technique has many advantages and has a preference for other econometrics techniques used in long-run relationships( Ahmad, Ahmad, Mushtaq and Nadeem, 2016).

The current study depends in its methodology on the methodology of Melih 2014, Dritsakis 2011 and Baharumshah, et al. (2009) which they used Autoregressive Distributed Lag (ARDL) Approach, Cointegration and long run form to test the relationship between demand for money and its determinants, with some modifications to the variables.

\subsubsection{The Model Specification}

The model includes Real money demand $\left(\mathrm{M}_{2}\right)$, real gross domestic product (RGDP), inflation rate(INR), real interest rate (INTR), and budget deficit (BD) which can be written in a semi$\log$ linear form as:

$$
\mathrm{LNM}_{2 \mathrm{t}}=\beta 0+\beta 1 \mathrm{LNINTR}_{\mathrm{t}}+\beta 2 \mathrm{BD}_{\mathrm{t}}+\beta 3 \mathrm{LN} \mathrm{INFR}_{\mathrm{t}}+\beta 4 \mathrm{LNRGDP}_{\mathrm{t}}+\mathrm{U}_{\mathrm{tn}}
$$

where $\mathrm{LNM}_{2}$ is natural logarithm of money demand, LNINTR is natural logarithm of real interest rate, BD is budget deficit, LNINFR is natural logarithm of inflation rate, LNRGDP is 
natural logarithm of real gross domestic product, $U$ is the error term, $\beta 0$ is the constant, $\beta 1, \beta 2$, $\beta 3, \beta 4$ are parameters (elasticity's), $t$ is the time.

An unrestricted Autoregressive Distributed Lagged (ARDL) representation of equation (1) is formulated as follows:

$$
\begin{aligned}
\Delta l N M 2 t=\beta 0 & +\sum_{i=1}^{n} \beta_{1} \Delta l N M 2_{t-i}+\sum_{i=0}^{n} \beta_{2} \Delta l N R G D P_{t-i}+\sum_{i=0}^{n} \beta_{3} \Delta l N I N T R_{t-i}+\sum_{i=0}^{n} \beta_{4} \Delta B D_{t-i} \\
& +\sum_{i=0}^{n} \beta_{5} \Delta I N F R_{t-i}+\beta_{6} l N M 2_{t-1}+\beta_{7} l N R G D P_{t-1}+\beta_{8} \operatorname{lnINTR}_{t-1}+\beta_{9} B D_{t-1} \\
& +\beta_{10} I N F R_{t-1}+U t
\end{aligned}
$$

Where $\Delta$ denotes the first difference, LNM2, Natural logarithm Of M2, LNGDP, natural logarithm of RGDP, LNINTR, natural logarithm of interest, $\beta 0$ is the constant, $U$ is the error term, $t$ is the time, the expressions with the summation $\operatorname{sign}(\beta 1, \beta 2, \beta 3, \beta 4, \beta 5)$ represents short run dynamics of the model. The expressions $(\beta 6, \beta 7, \beta 8, \beta 9, \beta 10)$ represents the long run relationship.

\subsubsection{Study Variables}

\subsection{2,1 Dependent Variable}

Real money demand $\left(\mathrm{M}_{2}\right)$ : broad money demand equals (M2/p). $\mathrm{p}$ is the general price level

\subsubsection{Independent Variables:}

Real Gross Domestic Product (RGDP): inflation-corrected gross domestic product equals (GDP/CP).

Real Interest Rate (INTR): The interest rate after excluding inflation.

Budget Deficit (BD): The difference between government spending and government revenues. budget deficit is not converted into natural logs because it has negative values.

Inflation Rate (INFR): Is the rate at which the overall level of price rises for goods and services.

\subsection{Study Hypotheses}

The study examines the following alternative hypotheses:

H1: There is a significant relationship between real gross domestic product and real money $\operatorname{demand}\left(\mathrm{M}_{2}\right)$.

$\mathrm{H} 2$ : There is a significant relationship between real interest rate and real money demand $\left(\mathrm{M}_{2}\right)$.

H3: There is a significant relationship between budget deficit and real money demand $\left(\mathrm{M}_{2}\right)$.

H4: There is a significant relationship between inflation rate and real money demand $\left(\mathrm{M}_{2}\right)$. 


\section{Empirical Results}

\subsection{Unit Root Test/ stationary Test}

stable time series data is a condition for using data in regression. Granger and Newbold (1974) who coined the term spurious regression, which uses time series data and shows a good regression because the values of $(\mathrm{t})$ indicate a statistically significant relationship between the two variables while this is a spurious regression. Augmented Dickey-Fuller (ADF), PhillipsPerron Test Equation (PP), Kwiatkowski-Phillips-SchmidtShin (KPSS), Elliott-RothenbergStock (ERS), Ng-Perron (NP) are the methods to test unit root of variables (Al-Qudah, 2014; and Eryigit, 2012). The Augmented Dickey Fuller test (ADF) is applied to test the stability for the quarterly time series of the study variables real money demand $\left(\mathrm{LNM}_{2}\right)$, interest rate (INTR) inflation (INFR), budget deficit (BD) and real gross domestic product (LNRGDP). From Table (1) the results of Augmented Dickey Fuller (ADF) unit root test, when we test for unit root test at level and (non trend, trend and intercept) that all variables except interest are not stationary at the level. The value of probability of the Augmented Dickey Fuller test (ADF) is greater than 5\%. Thus, we accept the null hypothesis that states that there is a unit root (time series is not stationary) for the study variables except interest rate and then we re-test, and after taking the first difference we found through (Augmented Dickey Fuller test (ADF)) and from the probability value which were less than $5 \%$, thus rejecting the null hypothesis and accepting the alternative hypothesis that states that there is no unit root or the time series of the study variables are stationary. This enables us to use ARDL which can be used when the times series are stationary at level I(0) or at first difference I(1) but can't be used with time series stationary at $\mathrm{I}(2)$. 
Table 1. Augmented Dickey Fuller (ADF) Unit Root Test

\begin{tabular}{|l|l|l|l|l|l|}
\hline Variable & $\begin{array}{l}\text { Calculated } \\
\text { ADF } \\
\text { Statistics }\end{array}$ & $\begin{array}{l}\text { 5\% ADF } \\
\text { Critical } \\
\text { Value }\end{array}$ & Probability & $\begin{array}{l}\text { Order of } \\
\text { Integration }\end{array}$ & $\begin{array}{l}\text { Stationary/ } \\
\text { Not } \\
\text { Stationary }\end{array}$ \\
\hline LNM $_{2}$ & 0.964426 & -2.90236 & 0.9958 & $\mathrm{I}(0)$ & $\begin{array}{l}\text { Not } \\
\text { stationary }\end{array}$ \\
\hline LNINR & -2.95579 & -2.9042 & 0.0443 & $\mathrm{I}(0)$ & Stationary \\
\hline BD & -2.05499 & -2.9042 & 0.2633 & $\mathrm{I}(0)$ & $\begin{array}{l}\text { Not } \\
\text { stationary }\end{array}$ \\
\hline INFR & -0.13734 & -2.90295 & 0.9406 & $\mathrm{I}(0)$ & $\begin{array}{l}\text { Not } \\
\text { stationary }\end{array}$ \\
\hline LNRGDP & -1.61552 & -2.90552 & 0.4692 & $\mathrm{I}(0)$ & $\begin{array}{l}\text { Not } \\
\text { stationary }\end{array}$ \\
\hline LNM 2 & -8.55041 & -2.90295 & 0.0000 & $\mathrm{I}(1)$ & Stationary \\
\hline LNINR & -6.65837 & -2.90295 & 0.0000 & $\mathrm{I}(1)$ & Stationary \\
\hline BD & -13.1883 & -2.9042 & 0.0001 & $\mathrm{I}(1)$ & Stationary \\
\hline INFR & -5.41299 & -2.90295 & 0.0000 & $\mathrm{I}(1)$ & Stationary \\
\hline LNRGDP & -86.181 & -3.47831 & 0.0001 & $\mathrm{I}(1)$ & Stationary \\
\hline
\end{tabular}

\subsection{Results and Discussion}

To use the ARDL approach, first it is necessary to test the existence of a long-run relationship between the study variables and to verify it we estimated unrestricted ARDL then we estimate bound test and compare the F-statistics of the bound test results with the upper critical value of bound (Pesaran) test. Second if the long run relationship between the study variables is proven, the restricted ARDL (cointegration and long run form) estimated (Anayochukwu ,2012).

\subsection{ARDL Bound test}

The hypothesis of the bound test is:

Ho: No long run relationship exist between variables.

$\mathrm{H} 1$ : There is a long run relationship exist between variables.

To examine the existence of long-run relationship between the study variables. To verify that we compare the F-statistics (as shown in table 2) with the critical value of upper bound(Pesaran) test. Our guide line if the F-Statistics value is greater than the upper bound (Pesaran) value at $5 \%$ we can reject the null hypothesis that states no long run relationship exist between variables and accept the alternative hypothesis that states there is a long run relationship exist between 
variables, if the F-Statistics value is less than the lower bound value at 5\% we can accept the null hypothesis that states no long run relationship . if the F-Statistics value lies between upper bound and lower bound critical values the result will be inconclusive.

\section{long run relationship examined by using Bound test}

Null Hypothesis: No long-run relationships exist

Table 2. bound test to cointegration

\begin{tabular}{|lll|}
\hline Test.Statistic & Value & K \\
\hline F-statistic & 15.91401 & 4 \\
\hline Critical Value & Bounds & \\
\hline Significance & I0 Bound & I1Bound \\
\hline $10 \%$ & 2.2 & 3.09 \\
\hline $5 \%$ & 2.56 & 3.49 \\
$2.50 \%$ & 2.88 & 3.87 \\
$1 \%$ & 3.29 & 4.37 \\
\hline
\end{tabular}

The results of bound test in table (2) show that the F-Statistics value is (15.91401) which is greater than the critical value of the upper bound value at $5 \%, 2.5 \%$ and $1 \%$ respectively So, we reject the null hypothesis that states no long run relationship exist between variables. and accept the alternative hypothesis that states there is a long run relationship between variables. So, it is proven that the model has long-run relationship (cointegration).

\subsection{ARDL Long Run Coefficients Results}

The ARDL bound test proven that the time series have long-run relationship, the coefficients of the long-run relationship are estimated by using maximum lag of 4 . The Akiak Information Criteria (AIC) had selected a model of ARDL $(0,0,0,0)$ specification.

1-from table (3) the interest rate (LNINTR) has a negative long run relationship with money demand $\left(\mathrm{M}_{2}\right)$ and it has a negative and significant impact at 1percent level on Money demand $\left(\mathrm{M}_{2}\right)$. since the elasticity is $(-0.26009)$ and the probability is $(0.0082)$ this means if the interest rate increased by 1 percent money demand $\left(\mathrm{M}_{2}\right)$ will decreased by $(0.26009)$. This is attributes to that if you look at the interest rate as the price of money then the high interest rate is offset by the low demand for money, since the increase in interest rates leads to a drop in demand for money because the owners of funds prefer to save their money to benefit from interest return. As for the borrowers, whether investors or consumers, the high interest rate means high cost of money and this leads to a drop in demand for money as it is known economically for most things that the high price leads to a drop in demand. This result is consistence with the result of (Achsani, 2010 and Dorgu, 2013).

2-The results show that inflation rate (LNINFR) has a positive long run relationship with Money demand $\left(\mathrm{M}_{2}\right)$ and it has a positive and significant impact 1percent level on Money demand $\left(\mathrm{M}_{2}\right)$. A 1percent increase in inflation rate will lead to 1.004376 percent increase in $\left(\mathrm{M}_{2}\right)$. The results indicate that more inflation rate will lead to high money demand. This is due to, that inflation determines the purchasing power of money and this means that the amount of 
money needed to buy a certain group of goods will increase with the high level of prices, so high inflation will lead to higher demand for money. The study result is consistence with result study of Abdullah, Chani, and Ali(2013).

3-The results show that real gross domestic product g (LNRGDP) has a positive long run relationship with money demand and its impact on $\left(\mathrm{M}_{2}\right)$ is positive and statistically significant at 1percent level. A 1percent increase in RGDP will lead to (1.114644) increase in $\left(\mathrm{M}_{2}\right)$. The results indicate that more real GDP growth will lead to high money demand. This is due to the fact that the increase in real gross domestic product increases the total demand for money to finance economic transactions. So, demand for money is a positive function proportional to the real output, as well as, at the real per capita income level, the increase in real per capita income leads to increase demand for money. This result is consistence with the result of Achsani, 2010 and Dorgu, 2013.

4-The results show that budget deficit $(\mathrm{BD})$ has a positive long run relationship with money demand $\left(\mathrm{M}_{2}\right)$ and Its impact on $\left(\mathrm{M}_{2}\right)$ is positive and statistically significant at 1 percent level. A 1percent increase in (BD) will lead to (0.000103) percent increase in money demand $\left(\mathrm{M}_{2}\right)$. The results indicate that more budget deficit will lead to more money demand. This is due to the increase in the budget deficit leads to increase borrowing to finance the deficit and thus increase spending, which leads to an increase in demand for money in the economy.

Table 3. ARDL(0.0.0.0) Long Run Coefficients Results

Dependent Variable: LNM2

\begin{tabular}{|c|c|c|c|c|}
\hline Variable & Coefficient & $\begin{array}{l}\text { Std. } \\
\text { Error }\end{array}$ & $\begin{array}{l}\mathrm{t}- \\
\text { Statistic }\end{array}$ & Prob. \\
\hline LNINT & -0.26009 & 0.094906 & -2.74047 & 0.0082 \\
\hline LNINFR & 1.004376 & 0.204734 & 4.905773 & 0 \\
\hline LNRGDP & 1.114644 & 0.173491 & 6.424787 & 0 \\
\hline $\mathrm{BD}$ & 0.000103 & 0.000059 & 1.756522 & 0.0844 \\
\hline $\mathrm{C}$ & -2.69044 & 0.645185 & -4.17003 & 0.0001 \\
\hline
\end{tabular}

\subsection{ARDL Short Run and Cointegration Results}

The estimates of the error correction model based on the associated long-run estimates. The maximum lag length is automatically selected by the method based on Akaike Information Criterion (AIC). According to AIC information criterions we found $\operatorname{ARDL}(1,0,0,2,1)$ as the best equation.

The coefficient of the Cointegration equation (CointEq1) which is called the error correction term ECM(-1)or the speed of adjustment toward equilibrium. Our guideline if coefficient is negative and significant we can say that there is a long run causality running from real interest rate (INTR) inflation rate (INFR), budget deficit (BD) and real gross domestic product (RGDP) to money demand $\left(\mathrm{M}_{2}\right)$, and if the coefficient of the cointegration equation (CointEq1) is not 
negative and not significant this means there is no long run causality running from real interest rate (INTR) inflation rate (INFR), budget deficit (BD) and real gross domestic product (RGDP) to money demand $\left(\mathrm{M}_{2}\right)$.

From Table (4) we can see that the sign of the coefficient of the cointegration equation (CointEq1) is negative and significant, since its probability is $(0.0000)$ which is less than 5\% percent. Therefore, there is a long run causality running from real interest rate (INTR), inflation rate (INFR), budget deficit (BD) and real gross domestic product (RGDP) to money demand $\left(\mathrm{M}_{2}\right)$, Bannerjee et al. (1998) holds that a highly significant error correction term is further proof of the existence of a stable long-term relationship. The estimated coefficient of the cointegration equation CointEq(-1) is $(-0.27884)$ (prob value $=0.000)$ suggesting that-in the absence of changes in other variables-deviation of the model from the long-term path is balanced by $(0.27884)$ increase in money demand per quarter year. This means that deviation from the long run relationship takes less than one year to be corrected. This result is consistent with the results of the studies of (Melih, 2014; Achsani, 2010; Abdulkhair, 2013; Dorgu, 2013; Dritsaksi, 2011; Baharumshah et al., 2009 and Samreh, 2008).

Table 4. ARDL Cointegration (Error correction) and Short Run Form Dependent Variable: LnM2 Selected Model: ARDL (1, 0, 0, 2, 1)

\begin{tabular}{|c|c|c|c|c|}
\hline Variable & Coefficient & $\begin{array}{l}\text { Std. } \\
\text { Error }\end{array}$ & $\begin{array}{l}\text { t- } \\
\text { Statistic }\end{array}$ & Prob. \\
\hline D(LNM2(-1)) & -0.18474 & 0.099092 & -1.86433 & 0.0674 \\
\hline $\mathrm{D}(\mathrm{LNINT})$ & -0.10643 & 0.064592 & -1.64773 & 0.1049 \\
\hline D(LNINFR) & 0.196233 & 0.112242 & 1.748298 & 0.0858 \\
\hline D(LNRGDP) & 0.163273 & 0.040338 & 4.047593 & 0.0002 \\
\hline $\begin{array}{l}\text { D(LNRGDP(- } \\
1))\end{array}$ & -0.16534 & 0.033832 & -4.88698 & 0 \\
\hline $\begin{array}{l}\text { D(LNRGDP(- } \\
\text { 2)) }\end{array}$ & -0.0863 & 0.04033 & -2.13981 & 0.0367 \\
\hline $\mathrm{D}(\mathrm{BD})$ & 0.000002 & 0.000006 & 0.285275 & 0.7765 \\
\hline $\mathrm{D}(\mathrm{BD}(-1))$ & $-1.3 \mathrm{E}-05$ & 0.000007 & -1.84575 & 0.0701 \\
\hline CointEq(-1) & -0.27884 & 0.031627 & -8.81629 & 0 \\
\hline
\end{tabular}

Table 4 shows short run results

1- The past period money demand has a negative and significant impact on money demand, the elasticity of lag value of money demand is (-0.18474) and the probability is (0.0674), which highlight a negative relationship with money demand in Jordan.

2-while the interest rate has a negative and not significant impact on money demand, the elasticity of interest rate is $(-0.10643)$ and its probability is $(0.1049)$ which indicates a negative relationship with money demand in Jordan. 


\section{Macrothink}

Journal of Management Research

ISSN 1941-899X

2019, Vol. 11, No. 1

3- inflation rate $\mathrm{D}$ (INFR) has a positive and significant impact on money demand, the elasticity of inflation rate is $(0.196233)$ and the probability is $(0.0858)$. This means that the inflation rate increases money demand by 0.196233 percent when it is increased by 1 percent keeping other variables fixed.

4- Gross domestic product has a positive and significant impact on money demand in Jordan. The elasticity of real GDP D(LNRGDP) is $(0.163273)$ and its probability is $(0.0002)$ which highlight a positive relationship with money demand in Jordan at 1 percent. also it points out that 1 percent increase in gross domestic product will increase money demand in Jordan by (0.163273) percent . lag (1) and lag (2) for gross domestic product have negative and significant impact on money demand in Jordan.

5-In short run budget deficit has a positive and not significant impact on money demand in Jordan. The elasticity of budget deficit is $(0.000002)$ and its probability is $(0.7765)$ which shows a positive relationship.

\section{6 long run CUSUM test Graph at 5\%}

A stable relationship between the demand for money and its determinants is a prerequisite for the formulation of monetary policy strategies (Sharifi-Renani 2007). The stability of long term coefficients is used to form the term error correction in conjunction with short term dynamics. In the light of that to confirm the stability of the estimated model, this study used Cumulative Sum (CUSUM) of recursive residuals and Cumulative Sum of Squares (CUSUMQ) of recursive residuals tests which was developed by Brown et al. (1975). The CUSUM test is based on the cumulative sum of recursive residuals based on the first set of $\mathrm{N}$ observations. It is updated recursively and is plotted against the break points. If the plot of CUSUM statistic stays within 5\% significance level, then estimated model is said to be stable (Dritsakis, 2011).

From figure (1) the plot of CUSUM statistics stays within 5\% significant level this means that the money demand (M2) estimated model is stable.

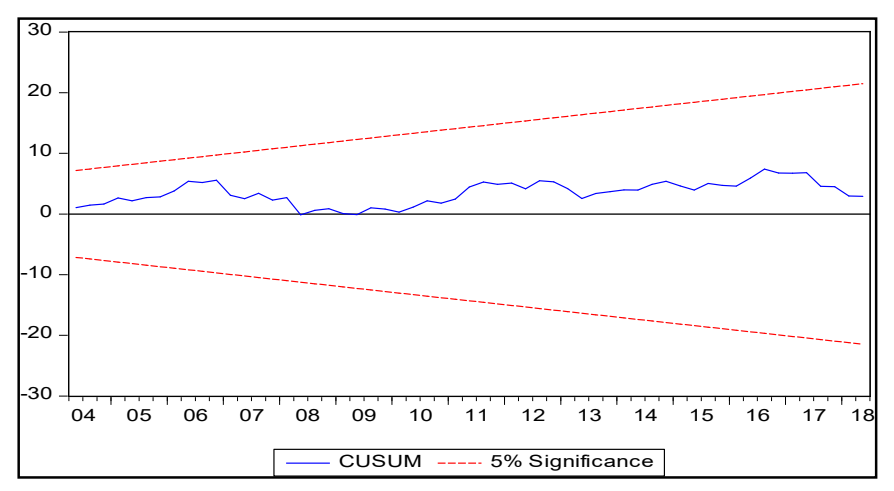

Figure 1. long run Cumulative Sum of Recursive Residuals (M2)

from figure (2) the plot of CUSUM of squares statistics stays within 5\% significant level this means that the money demand M2 estimated model is stable. 


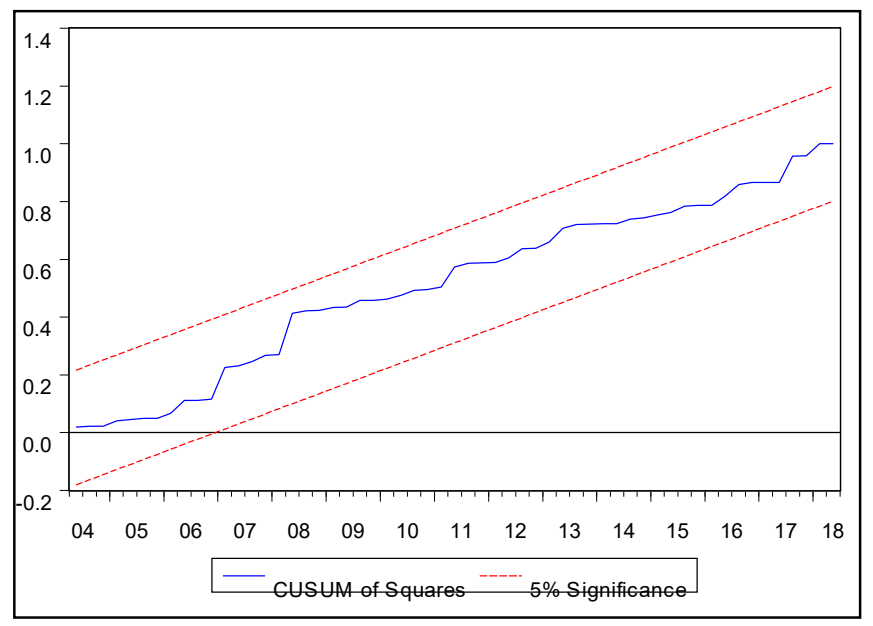

Figure 2. long run Cumulative Sum of Squares of Recursive Residuals (M2)

\subsection{Unrestricted Autoregressive Distributed Lagged (ARDL) Estimation Results}

The maximum lag length is automatically selected by the method based on Akaike Information Criterion (AIC). According to AIC information criterions we found $\operatorname{ARDL}(2,0,0,3,2)$ as the best model by (automatic selection lags).

from table (5) R-square value is (0.999343) and adjusted $\mathrm{R}$ square value is (0.999185) shows that the econometrics model explain more than $99 \%$ of the change in money demand $\left(\mathrm{M}_{2}\right)$ in Jordan and this indicates that the model is fit. The F-Statistic value is (6320.615) and its probability $(0.000)$ indicates that the explanatory variables are jointly significant and are capable of explaining changes in real money demand $\left(\mathrm{M}_{2}\right)$ in Jordan. 


\section{1) Macrothink}

Table 5. Unrestricted Autoregressive Distributed Lag (ARDL) Results

Estimation Results (Dependent Variable : LNM2

Model selection method: Akaike Information Criterion (AIC). Automatic selection lags.

Selected Model: $\operatorname{ARDL}(2,0,0,3,2)$

\begin{tabular}{|lrlrr|}
\hline & \multicolumn{3}{l}{ Std. } & \\
\hline & Coefficient & Error & t-Statistic & Prob. ${ }^{*}$ \\
LNM2(-1) & 0.541313 & 0.120282 & 4.500381 & 0 \\
\hline LNM2(-2) & 0.186456 & 0.104906 & 1.777365 & 0.0808 \\
\hline LNINT & -0.0708 & 0.025976 & -2.72571 & 0.0085 \\
\hline LNINFR & 0.273422 & 0.078936 & 3.463843 & 0.001 \\
\hline LNRGDP & 0.159836 & 0.045016 & 3.550601 & 0.0008 \\
\hline LNRGDP(-1) & -0.0151 & 0.050103 & -0.30145 & 0.7642 \\
\hline LNRGDP(-2) & 0.074696 & 0.045128 & 1.655189 & 0.1034 \\
\hline LNRGDP(-3) & 0.084013 & 0.042911 & 1.957816 & 0.0552 \\
\hline BUDGETD & $1.89 \mathrm{E}-06$ & $8.15 \mathrm{E}-06$ & 0.231496 & 0.8178 \\
\hline BUDGETD(-1) & $1.46 \mathrm{E}-05$ & $8.79 \mathrm{E}-06$ & 1.663569 & 0.1017 \\
\hline BUDGETD(-2) & $1.16 \mathrm{E}-05$ & $8.76 \mathrm{E}-06$ & 1.329323 & 0.189 \\
\hline C & -0.73242 & 0.223823 & -3.27233 & 0.0018 \\
\hline R-squared & 0.999445 & & & \\
\hline $\begin{array}{l}\text { Adjusted R- } \\
\text { squared }\end{array}$ & 0.999338 & & & \\
\hline F-statistic & 9332.714 & & & \\
\hline Prob(F-statistic) & & & & \\
\hline
\end{tabular}

\subsection{Residual Diagnostics}

From the following diagnostic tests, we can see that the model passes three tests, normality, autocorrelation and heteroskedasticity.

1-Histogram Normality Test.

Most of parametric tests rely on the assumption of the normal distribution of variables and the deviation from normal distribution makes parametric tests imprecise. Johnston and Dinardo (1997). The Histogram-Normality Test was used to check whether the model residuals are normally distributed or not. The result in table (6) shows that the probability of Jarque-Bera is (0.4092918) which its more than $5 \%$, this means that the model residuals are normally distributed. 


\section{1) Macrothink}

Table 6. Histogram-Normality Test

\begin{tabular}{|l|l|}
\hline Jarque-Bera & 1.414824 \\
\hline Probability & 0.4092918 \\
\hline
\end{tabular}

\section{2-Autocorrelation Test}

One of the basic assumptions in the linear regression model is that random error terms are independent (Green, 2008). The Breusch-Godfrey Serial Correlation LM Test was used to check whether there is an autocorrelation between the random error terms of the observations in a regression or not. The results in Table (7) show that the Obs-R-squared probability is $(0.2219)$ which its more than $5 \%$ this means that there is no auto-correlation between the error term of the observations.

Table 7. Results of Autocorrelation Test

\begin{tabular}{|lrll|}
\hline \multicolumn{4}{|l|}{ Breusch-Godfrey Serial Correlation LM Test: } \\
\hline F-statistic & 1.23759 & Prob. F(1,56) & 0.2707 \\
\hline & \multicolumn{3}{|c}{ Prob. Chi- } \\
Obs*R-squared & 1.491916 & Square(1) & 0.2219 \\
\hline
\end{tabular}

\section{3-Heteroskedasticity Test}

One of the basic assumptions in linear regression model is that the standard errors of the estimates must be homogeneous (Maddala, 2002). Breusch-Pagan-Godfrey test was used to check whether the error term of the residuals of the model are heteroskedasticity or not. The result in Table (8) shows that the Obs- R-squared probability is $(0.3264)$ which is more than $5 \%$ and this means that the residuals of the model are not heteroskedasticity or they are homoskedasticity.

Table 8. Results of the Heteroskedasticity Test

\begin{tabular}{|lrll|}
\hline \multicolumn{4}{|l|}{ Heteroskedasticity Test: Breusch-Pagan-Godfrey } \\
\hline F-statistic & 1.147856 & Prob. F(11,57) & 0.3433 \\
\hline & \multicolumn{4}{|c|}{ Prob. Chi- } \\
Obs*R-squared & 12.51282 & Square(11) & 0.3264 \\
\hline
\end{tabular}

\section{Conclusions}

The current study investigated the relationship between money demand $\left(\mathrm{M}_{2}\right)$ and interest rate, inflation rate, gross domestic product and budget deficit. By using quarterly time series data for the period (2000Q1 to 2018Q1). The study used unit root test, Autoregressive Distributive Lagged Model (ARDL) Approach Cointegration and long run form and ARDL Bound test, to examine the study hypotheses. In addition, Cumulative Sum (CUSUM) of recursive residuals and Cumulative Sum of Squares (CUSUMQ) of recursive residuals tests are used to confirm the stability of the estimated model.

1-The estimated coefficient of the cointegration equation (CointEq1) is negative and significant, which indicates that there is a cointegration or long run relationship between real interest rate 
(INTR) inflation rate (INFR), budget deficit (BD) real gross domestic product (RGDP) and money demand $\left(\mathrm{M}_{2}\right)$, The estimated coefficient of the cointegration equation CointEq(-1) is ($0.27884)$ (prob value $=0.000)$.

2-The short run ARDL results shows that the past period money demand has a negative and significant impact on money demand, while inflation rate (INFR) and Gross domestic product have a positive and significant impact on money demand in Jordan.

3- The results of bound test shows that there is a long run relationship exist between real interest rate (INTR) inflation rate (INFR), budget deficit (BD) real gross domestic product (RGDP) and money demand $\left(\mathrm{M}_{2}\right)$ and this result confirms the results of cointegration equation (CointEq1) and proofs that the model has long-run relationship (cointegration).

4-The long run ARDL results show

a) that the interest rate (LNINTR) has a negative long run relationship with money demand $\left(\mathrm{M}_{2}\right)$ and it has a negative and significant impact at 1percent level on Money demand $\left(\mathrm{M}_{2}\right)$. This is because the rate of interest is the price of money and the increase in the interest rate encourages savers to deposit their money in banks to benefit from return on their savings. While rising interest rates raise borrowing costs for consumers and investors, reducing their ability to borrow and reducing money demand.

The results show that inflation rate (LNINFR) has a positive long run relationship with Money demand $\left(\mathrm{M}_{2}\right)$ and it has a positive and significant impact at 1percent level on Money demand $\left(\mathrm{M}_{2}\right)$. This is because inflation leads to reduce the purchasing power of money, which increases the demand for money to buy the same quantity of goods and services.

b) The results show that real gross domestic product (LNRGDP) has a positive long run relationship with money demand and its impact on $\left(\mathrm{M}_{2}\right)$ is positive and statistically significant at 1 percent level. This is because the increase in gross domestic product leads to increase demand for money by investors to resolve payments in the economy as well as the increase in gross domestic product leads to an increase in income of individuals, which leads to increase demand for goods and services and this leads to an increase in demand for money, Gross domestic product generally causes increase demand for money.

c)The results show that budget deficit (BD) has a positive long run relationship with money demand $\left(\mathrm{M}_{2}\right)$ and Its impact on $\left(\mathrm{M}_{2}\right)$ is positive and statistically significant at 1 percent level. This is attributed to the increase in the deficit of the public budget is pushing the government to increase borrowing and this leads to increase public spending, which requires increase demand for money.

5- The stability tests Cumulative Sum (CUSUM) of recursive residuals and Cumulative Sum of Squares (CUSUMQ) of recursive residuals confirm that the money demand estimated model is stable.

The policy implication of the study is that the results showed that there is a long-run relationship between the demand for real money M2 and its determinants real interest rate, inflation rate, budget deficit and real gross domestic product, as well as that the demand for 
money is stable in Jordan during the study period. This leads to conclusion that M2 is the best and most reasonable monetary aggregate in designing a stable monetary policy that contributes to maintaining economic growth and control inflation rates, interest rates and budget deficits.

\section{References}

Abakpa, A., Purokayo, S. G., Asaph, P, P., \& Asaph, P. P. (2018). Analysis of the determinants of money supply in Nigeria. International Journal of Scientific Research, III(2).

Abdulkheir, A., Y. (2013) An analytical study of the demand for money in Saudi Arabia, International Journal of Economics and Finance, 5(4). https://doi.org/10.5539/ijef.v5n4p31

Abdullah, M., Chani,M. I., \& Ali, A. (2013). Determinants of money demand in Pakistan: disaggregated expenditure approach, World Applied Sciences Journal, 24(6), 765-77.

Achsani, N.A. (2010). Stability of money demand in an emerging market economy: An Error Correction and ARDL Model for Indonesia”, Research Journal of International Studies, 13, 83-91, Indonesia.

Al-Qudah, A. (2014). Stock exchange development and economic growth: empirical evidence from Jordan, International Journal of Business and management, 9(11). https://doi.org/10.5539/ijbm.v9n11p123

Baharumshah, A., Siti, H. M., \& Mansur, M. (2009). The stability of money demand in China: Evidence from the ARDL model, Economic Systems, 33(3), 231-244. https://doi.org/10.1016/j.ecosys.2009.06.001

Brown, R., Durbin, J., \& Evans, J. (1975). Techniques for testing the constancy of regression relations over time, Journal of the Royal Statistical Society, 37: 149-192.

Doğru,B., \& Recepoğlu, M (2013). Dynamic analysis of money demand function in Turkey, International Journal of Economics and Finance, 5(9). https://doi.org/10.5539/ijef.v5n9p20

Dritsakis, N. (2011). Demand for money in Hungary: An ARDL Approach . Review of Economics \& Finance, 1, 01-16.

Ebele, I., \& Omotayo, A. (2015) Macroeconomic variables and money supply: evidence from Nigeria, African Research Review, 9(4), Serial No. 39.

Eryigit, M. (2012). The dynamic relationship between oil price shocks and macroeconomic variables in Turkey. Economic Research - Ekonomska istraživanja, 25(2), 263-276. https://doi.org/10.1080/1331677X.2012.11517507

Granger. C, \& Newbold, P. (1974). Spurious regression in econometrics, Journal of Econometrics, 2, 111-120. https://doi.org/10.1016/0304-4076(74)90034-7

Green, W. (2008). Econometrics analysis, Prentice Hall, sixth edition.

Johansen, S. (1988). Statistical analysis of cointegration vectors. Journal of Economic Dynamics and Control, 12, 231-254. https://doi.org/10.1016/0165-1889(88)90041-3 
Johansen, S, \& Juselius, K. (1990). Maximum likelihood estimation and inference on cointegration: with applications to the demand for money. Oxford Bulletin of Economics and Statistics, 52, 169-210. https://doi.org/10.1111/j.1468-0084.1990.mp52002003.x

Johansen, S. (1991). Estimation and hypothesis testing of co-integration vectors in Gaussian vector autoregressive models. Econometrica, 59, 1551-1580. https://doi.org/10.2307/2938278

Johansen, S. (1991). Estimation and hypothesis testing of co-integration vectors in Gaussian vector autoregressive models. Econometrica, 59, 1551-1580. https://doi.org/10.2307/2938278

Johansen, S. (1988). Statistical analysis of cointegration vectors. Journal of Economics Dynamics and Controls, 12, 231-254. https://doi.org/10.1016/0165-1889(88)90041-3

Johnston, J., \& Dinardo, J. (1997). Econometric methods, McGraw Hill, Fourth edition.

Maddala, G. (2002). Introduction to econometrics, John Willey, Third edition.

Maravić, Jelana, \& Mirjana Palić. (2010). Econometric analysis of money demand in Serbia, Working Paper.

ÖZÇALIK, M. (2014). Money demand function in Turkey: an ARDL approach. The Journal of Social and Economic Research, 14(27).

Pesaran, M. H., \& B. Pesaran. (1997). Working with Microfit 4.0: Interactive Econometric Analysis. Oxford: Oxford University Press.

Pesaran, M. H. and Y. Shin (1995), An autoregressive distributed lag modeling approach to cointegration analysis. In Centennial Volume of Ranger Frisch edited by S. Storm, A. Holly and P. Diamond. Cambridge: Cambridge University Press.

Pesaran, M. H. and Y. Shin (1999), an autoregressive distributed lag modeling approach to cointegration analysis. In Strom, S. (ed.), Econometrics and Economic Theory in the 20th Century: The Ragnar Frisch Centennial Symposium. Cambridge: Cambridge University Press.

Pesaran, M. H., Shin, Y., \& Smith, R. J. (2001). Bounds testing approaches to the analysis of level relationships. Journal of applied econometrics, 16(3), 289-326. https://doi.org/10.1017/CCOL521633230.011

Samreth, S., (2008), Estimating money demand function in Cambodia: ARDL Approach, MPRA Paper No. 16274.

Sharifi-Renani, H. (2007). Demand for money in Iran: An ARDL approach, MPRA Paper No. 8224 .

Stock, S. H., \& Watson, M. W. (1988). Testing for common trends, Discussion Paper Series, John Fitzgerald Kennedy School of Government, Harvard University, USA. 